\title{
Editorial: Smart Cities and Regions
}

\author{
Chris McPhee, Editor-in-Chief
}

\section{Taina Tukiainen, Seppo Leminen, and Mika Westerlund, Guest Editors}

\section{From the Editor-in-Chief}

Welcome to the December 2016 issue of the Technology Innovation Management Review. In this issue, we revisit the theme of Smart Cities and Regions, and it is my pleasure to welcome back our three guest editors: Taina Tukiainen, Senior Researcher at Aalto University in Espoo, Finland, Seppo Leminen, Principal Lecturer at the Laurea University of Applied Sciences and Adjunct Professor in the School of Business at Aalto University in Finland, and Mika Westerlund, Associate Professor at Carleton University's Sprott School of Business in Ottawa, Canada.

In January and February, we will explore the popular theme of Living Labs in collaboration with the European Network of Living Labs (ENoLL; openlivinglabs.eu).

We hope you enjoy this issue of the TIM Review and will share your comments online. We welcome your submissions of articles on technology entrepreneurship, innovation management, and other topics relevant to launching and growing technology companies and solving practical problems in emerging domains. Please contact us (timreview.ca/contact) with potential article topics and submissions.

\section{Chris McPhee}

Editor-in-Chief

\section{From the Guest Editors}

We are pleased to introduce the second thematic issue on Smart Cities and Regions in the TIM Review. This issue focuses on explaining how regions and cities are getting smart, and we acknowledge Dameri (2013), who defines a smart city as:

"a well-defined geographical area, in which high technologies such as ICT, logistic, energy production, and so on, cooperate to create benefits for citizens in terms of well-being, inclusion and participation, environmental quality, intelligent development; it is governed by a well-defined pool of subjects, able to state the rules and policy for the city government and development."

The discussion on smart cities and regions is expanding rapidly, and more and more practitioners and researchers are involved in the debate (Leminen \& Westerlund, 2015; McPhee et al., 2015; Tukiainen et al., 2015). We hope that this special issue will further the debate on this topic, and we propose that future research should emphasize the intersection of smart cities and living labs, because these bodies of literature discuss some of the same thematic areas, particularly through living labs facilitated in a city context for the improvement of the daily lives of citizens (e.g., Leminen et al., 2012).

This issue of the TIM Review contributes five theoretically and practically oriented articles for researchers, managers, and innovation developers wishing to benefit from the emerging opportunities in the smart city domain. The selected articles incorporate smart city activities, particularly addressing work on regional innovation ecosystems taking place today in Europe and introducing frameworks and approaches to be used for business creation, opportunities and challenges in collaboration in smart cities, as well as best practices and contributions to smarter regions. In this vein, the issue continues the discussion initiated in the October 2015 issue of the TIM Review: timreview.ca/issue/2015/october

The first article, by Jukka Viitanen, CEO and Managing Partner of Resolute HQ Inc., discusses the differences in regions and raises the question of how sub-optimal innovation ecosystems can become more similar to forerunners. He takes the global best practice perspective to 


\title{
Editorial: Smart Cities and Regions
}

\author{
Chris McPhee, Taina Tukiainen, Seppo Leminen, and Mika Westerlund
}

developing innovation hubs, and offers a novel, holistic regional innovation hub framework to manage such ecosystems. The framework combines public and private sector interests for joint innovation activities, and is tested and validated through a case study of Cambridge, United Kingdom.

The second article, by Karlos Artto, Riikka Kyrö, Antti Peltokorpi, and Kristiina Sandqvist from Aalto University and Tuomas Ahola from Tampere University of Technology in Finland, introduces the Cuckoo's Nest approach, which highlights the need for integrating expert organizations to design systems and assigning organizations' design rights. The approach proposes that, in contrast to many development actions, the needs of the ecosystem come first and the goals and design features of single organizations follow on from the ecosystem's goals. The authors illustrate the approach using the outcomes of two workshops in the metropolitan area of Helsinki, Finland.

In the third article, Jukka Ojasalo and Lassi Tähtinen from Laurea University of Applied Sciences in Finland seek to increase knowledge of how to integrate open innovation platforms into public sector decision-making processes. They create and discuss an open innovation platform model for public sector decision making in a city based on a qualitative. explorative study. In particular, the study addressed different types of relationships in the platform. Ultimately, the model has several practical implications as it can be used as the starting point for collaborative innovation in cities and to show ways of breaking silos in the conventional bureaucratic model.

The fourth article, by Jukka Ojasalo and Heini Kauppinen from Laurea University of Applied Sciences in Finland, aims to increase understanding of the opportunities and challenges of collaborative innovation between a city and various external actors, such as companies, research institutions, and citizens. The authors discuss multiple types of opportunities and challenges for collaborative innovations in a city. The study concludes by offering research and policy recommendations to city governments and proposed future avenues for research on collaborative innovation in cities.
In the fifth article, Hanne Melin and Samuel Laurinkari from eBay along with Taina Tukiainen from Aalto University, Finland, ask: "How can online platforms contribute to smarter and more prosperous regions in Europe?" The authors discuss the costs of distance as a key issue in commerce in Europe and abroad, and they argue that the decentralized nature of digital commerce helps to foster economic growth and entrepreneurial activity. They also describe new emerging economic hotspots and propose a shift from regional variation towards regional integration.

We hope that the diverse perspectives offered in these articles will help scholars and managers to better understand the multifaceted phenomena of smart cities and regions, and will encourage them to help develop and discuss the concepts further.

\section{Taina Tukiainen, Seppo Leminen, and Mika Westerlund Guest Editors}

\section{References}

Dameri, R. P. 2013. Searching for Smart City Definition: A Comprehensive Proposal. International Journal of Computers \& Technology, 11(5): 2544-2551.

Leminen, S., \& Westerlund, M. 2015. Cities as Labs: Towards Collaborative Innovation in Cities. In P. Lappalainen, M. Markkula, \& H. Kune (Eds.), Orchestrating Regional Innovation Ecosystems: Espoo Innovation Garden: 167-175. Espoo, Finland: Otavan Kirjapaino Oy.

Leminen, S., Westerlund, M., \& Nyström, A.-G. 2012. Living Labs as Open-Innovation Networks. Technology Innovation Management Review, 2(9): 6-11.

http://timreview.ca/article/602

McPhee, C., Tukiainen, T., Leminen, S., \& Westerlund, M. 2015. Editorial: Smart Cities and Regions. Technology Innovation Management Review, 5(10) 3-6. http://timreview.ca/article/931

Tukiainen, T., Leminen, S., \& Westerlund, M. 2015. Cities as Collaborative Innovation Platforms. Technology Innovation Management Review, 5(10): 16-23.

http://timreview.ca/article/933 


\section{Editorial: Smart Cities and Regions}

\section{Chris McPhee, Taina Tukiainen, Seppo Leminen, and Mika Westerlund}

\section{About the Editors}

Chris McPhee is Editor-in-Chief of the Technology Innovation Management Review. He holds an MASc degree in Technology Innovation Management from Carleton University in Ottawa, Canada, and BScH and MSc degrees in Biology from Queen's University in Kingston, Canada. Chris has over 15 years of management, design, and content-development experience in Canada and Scotland, primarily in the science, health, and education sectors. As an advisor and editor, he helps entrepreneurs, executives, and researchers develop and express their ideas.

Taina Tukiainen is a Senior Researcher at Aalto University in Espoo, Finland, and she is a Cabinet Member of the President of the EU Committee of the Regions (CoR). She has worked for over 20 years within industry and universities and for over 10 years at Nokia Corporation as a senior manager, and she has worked on various projects with international university and industry collaboration. She was, until 2014, Director of Digibusiness Finland. Her research interest is strategic research including innovation, technology management, and entrepreneurship. Taina's doctoral dissertation was The Unexpected Benefits of Internal Corporate Ventures: An Empirical Examination of the Consequences of Investment in Corporate Ventures (2004), and the title of her latest book was The Finnish Startups in Globally Evolving Ecosystems: Value for Finland (2014).
Seppo Leminen holds positions as Principal Lecturer at the Laurea University of Applied Sciences and Adjunct Professor in the School of Business at Aalto University in Finland. He holds a doctoral degree in Marketing from the Hanken School of Economics and a doctoral degree in Industrial Engineering and Management in the School of Science at Aalto University. His research and consulting interests include living labs, open innovation, value cocreation and capture with users, relationships, services and business models in marketing, particularly in Internet of Things (IoT), as well as management models in high-tech and serviceintensive industries. Results from his research have been reported in Industrial Marketing Management, the Journal of Business Industrial Marketing, the Journal of Technology and Engineering and Management, Management Decision, the International Journal of Technology Management, the International Journal of Technology Marketing, the International Journal of Product Development, and the Technology Innovation Management Review, among many others

Mika Westerlund, DSc (Econ), is an Associate Professor at Carleton University in Ottawa, Canada. He previously held positions as a Postdoctoral Scholar in the Haas School of Business at the University of California Berkeley and in the School of Economics at Aalto University in Helsinki, Finland. Mika earned his doctoral degree in Marketing from the Helsinki School of Economics in Finland. His current research interests include open and user innovation, the Internet of Things, business strategy, and management models in high-tech and serviceintensive industries.

Citation: McPhee, C., Tukianen, T., Leminen, S., \&

Westerlund, M. 2016. Editorial: Smart Cities and

Regions. Technology Innovation Management Review,

6(12) 3-5. http://timreview.ca/article/1037

Keywords: smart cities, smart regions, ecosystems, living labs, collaborative innovation, open innovation, regional innovation, online platforms 